\title{
SOME RECENT DEVELOPMENTS REGARDING THE EUROPEAN UNION FISCAL POSITION
}

\author{
Iulia Andreea Bucur \\ "Vasile Alecsandri" University of Bacau \\ andreea.bucur@ub.ro \\ Liviana Andreea Niminet \\ "Vasile Alecsandri" University of Bacau \\ liviananiminet@yahoo.com \\ Silviu Mihai Silivestru \\ "Vasile Alecsandri" University of Bacau \\ silivestru.silviumihai@yahoo.com
}

\begin{abstract}
During the last decade, fiscal policies in the euro area and structural reforms in the European Union's countries that experienced different fiscal problems were a priority for the EU decisionmakers. The existence of sound and sustainable public finances in the EU and, in particular, in the euro area is based, on the one hand, on macroeconomic stability, and on the other hand, on balanced and sustainable economic growth. This paper focuses on capturing the recent developments in public finances, more precisely some indicators essential for assessing the health of the EU economy and of its Member States. The results of our research show an improvement of them, as a whole, as an effect of structural reforms, investments and also of responsible fiscal-budgetary policies.
\end{abstract}

\section{Keywords}

European Union; Euro area; public finance; general government deficit/surplus, general government gross debt; gross domestic product (GDP)

\section{JEL Classification}

E62; F36; H6

\section{Introduction}

In the context of excessive macroeconomic imbalances and financial tensions in the EU, its Member States experience various situations regarding general government gross debt and general government deficit/surplus, as a percentage of gross domestic product (GDP). In order to analyze their trends, we used Eurostat data, from 2015 to 2018. The obtained results allow us to appreciate that during the analyzed period, the European Union has made progress in correcting macroeconomic imbalances, while some aspects of vulnerability still exist.

\section{Some regulatory aspects}

The European Union public finance, overall, face major challenges arising from the need to reduce the level of indebtedness, of the pressure on long-term expenditures and of fiscal burden which is quite high (Bucur, Dragomirescu, 2013).

According to the Treaty on the Functioning of the European Union, the basic rule of budgetary policy is that "Member States shall avoid excessive government deficits" and prove sound public finances by complying with the reference values of $3 \%$ and, respectively, of $60 \%$ of the GDP for budget deficit and public debt. 
In the light of the Treaty, "at least once every two years, or at the request of a Member State with a derogation, the Commission and the European Central Bank shall report to the Council on the progress made by the Member States with a derogation in fulfiling their obligations regarding the achievement of economic and monetary union" (Article 140(1)). These reports examine, among others, fiscal developments, more precisely the extent to which each Member State met the criteria of "the sustainability of the government financial position" as an achievement of "a government budgetary position without a deficit that is excessive as determined in accordance with Article 126(6)" (Treaty on the Functioning of the European Union).

Governed by Article 126 of the Treaty, the excessive deficits procedure (EDP) mentions that if a Member State does not fulfil the requirements regarding fiscal discipline, the European Commission shall prepare a report when the ratio between the public deficit and the GDP exceeds the reference value, unless the ratio has decreased significantly and steadily and reaches a level close to the reference value, or if its exceedance is exceptional and temporary and the ratio remains close to the reference value, or when the ratio between public debt and GDP exceeds the reference value, unless this ratio is sufficiently diminished and approaches the reference value at a satisfactory rate.

\section{Data and findings}

In this context, we analyzed the evolution of the two indicators: general government deficit and gross public debt of the EU Member States, from 2015 to 2018. Thus, during the considered period, the EU-28's government deficit-to-GDP decreased from $-2.3 \%$ in 2015 to $-0.6 \%$ in 2018 , and of EA-19's decreased from $-2 \%$ in 2015 to $-0.5 \%$ in 2018 (Table 1).

Table 1 General government deficit/surplus in the EU, 2015-2018 (\% of GDP)

\begin{tabular}{lcccc} 
& $\mathbf{2 0 1 5}$ & $\mathbf{2 0 1 6}$ & $\mathbf{2 0 1 7}$ & $\mathbf{2 0 1 8}$ \\
\hline Luxembourg & 1,4 & 1,9 & 1,4 & 2,4 \\
\hline Bulgaria & $-1,7$ & 0,1 & 1,2 & 2 \\
\hline Malta & -1 & 0,9 & 3,4 & 2 \\
\hline Germany & 0,8 & 0,9 & 1 & 1,7 \\
\hline Netherlands & -2 & 0 & 1,2 & 1,5 \\
\hline Greece & $\mathbf{- 5 , 6}$ & 0,5 & 0,7 & 1,1 \\
\hline Czech Republic & $-0,6$ & 0,7 & 1,6 & 0,9 \\
\hline Sweden & 0 & 1 & 1,4 & 0,9 \\
\hline Lithuania & $-0,3$ & 0,2 & 0,5 & 0,7 \\
\hline Slovenia & $-2,8$ & $-1,9$ & 0 & 0,7 \\
\hline Denmark & $-1,3$ & $-0,1$ & 1,4 & 0,5 \\
\hline Croatia & $-3,2$ & -1 & 0,8 & 0,2 \\
\hline Austria & -1 & $-1,6$ & $-0,8$ & 0,1 \\
\hline Ireland & $-1,9$ & $-0,7$ & $-0,3$ & 0 \\
\hline Poland & $-2,7$ & $-2,2$ & $-1,5$ & $-0,4$ \\
\hline Portugal & $-4,4$ & -2 & -3 & $-0,5$ \\
\hline EA-19 & $\mathbf{- 2}$ & $\mathbf{- 1 , 6}$ & $\mathbf{- 1}$ & $\mathbf{- 0 , 5}$ \\
\hline Estonia & 0,1 & $-0,3$ & $-0,4$ & $-0,6$ \\
\hline EU-28 & $\mathbf{- 2 , 3}$ & $\mathbf{- 1 , 7}$ & $\mathbf{- 1}$ & $\mathbf{- 0 , 6}$ \\
\hline Belgium & $-2,4$ & $-2,4$ & $-0,8$ & $-0,7$ \\
\hline Slovakia & $-2,6$ & $-2,2$ & $-0,8$ & $-0,7$ \\
\hline Finland & $-2,8$ & $-1,7$ & $-0,8$ & $-0,7$ \\
\hline Latvia & $-1,4$ & 0,1 & $-0,6$ & -1 \\
\hline United Kingdom & $-4,2$ & $-2,9$ & $-1,9$ & $-1,5$ \\
\hline Italy & $-2,6$ & $-2,5$ & $-2,4$ & $-2,1$ \\
\hline Hungary & $-1,9$ & $-1,6$ & $-2,2$ & $-2,2$ \\
\hline Spain & $-5,3$ & $\mathbf{- 4 , 5}$ & $\mathbf{- 3 , 1}$ & $-2,5$ \\
\hline France & $-3,6$ & $-3,5$ & $-2,8$ & $-2,5$ \\
\hline Romania & $-0,7$ & $-2,7$ & $-2,7$ & -3 \\
\hline Cyprus & $-1,3$ & 0,3 & 1,8 & $\mathbf{- 4 , 8}$ \\
\hline Source: Eurostat & & & \\
\hline
\end{tabular}


As for EU-28's public debt, its level (as a percentage of GDP) decreased from 84.6\% in 2015 to $80.0 \%$ in 2018 and of EA-19's decreased from $90.1 \%$ to $85.1 \%$ during the same years (Table 2).

Table 2 Public debt in the European Union, 2015-2018 (\% of GDP)

\begin{tabular}{|c|c|c|c|c|}
\hline & 2015 & 2016 & 2017 & 2018 \\
\hline Estonia & 9,9 & 9,2 & 9,2 & 8,4 \\
\hline Luxembourg & 22,2 & 20,7 & 23,0 & 21,4 \\
\hline Bulgaria & 26,2 & 29,6 & 25,6 & 22,6 \\
\hline Czech Republic & 40,0 & 36,8 & 34,7 & 32,7 \\
\hline Denmark & 39,8 & 37,2 & 35,5 & 34,1 \\
\hline Lithuania & 42,6 & 40,0 & 39,4 & 34,2 \\
\hline Romania & 37,8 & 37,3 & 35,2 & 35,0 \\
\hline Latvia & 36,8 & 40,3 & 40,0 & 35,9 \\
\hline Sweden & 44,2 & 42,4 & 40,8 & 38,8 \\
\hline Malta & 57,9 & 55,5 & 50,2 & 46,0 \\
\hline Poland & 51,3 & 54,2 & 50,6 & 48,9 \\
\hline Slovakia & 52,2 & 51,8 & 50,9 & 48,9 \\
\hline Netherlands & 64,6 & 61,9 & 57,0 & 52,4 \\
\hline Finland & 63,4 & 63,0 & 61,3 & 58,9 \\
\hline Germany & 71,6 & 68,5 & 64,5 & 60,9 \\
\hline Irland & 76,8 & 73,5 & 68,5 & 64,8 \\
\hline Slovenia & 82,6 & 78,7 & 74,1 & 70,1 \\
\hline Hungary & 76,7 & 76,0 & 73,4 & 70,8 \\
\hline Austria & 84,7 & 83,0 & 78,2 & 73,8 \\
\hline Croatia & 83,7 & 80,5 & 77,8 & 74,6 \\
\hline EU-28 & 84,6 & 83,4 & 81,7 & 80,0 \\
\hline EA-19 & 90,1 & 89,2 & 87,1 & 85,1 \\
\hline United Kingdom & 87,9 & 87,9 & 87,1 & 86,8 \\
\hline Spain & 99,3 & 99,0 & 98,1 & 97,1 \\
\hline France & 95,6 & 98,0 & 98,4 & 98,4 \\
\hline Belgium & 106,4 & 106,1 & 103,4 & 102,0 \\
\hline Cyprus & 108,0 & 105,5 & 95,8 & 102,5 \\
\hline Portugal & 128,8 & 129,2 & 124,8 & 121,5 \\
\hline Italy & 131,6 & 131,4 & 131,4 & 132,2 \\
\hline Greece & 175,9 & 178,5 & 176,2 & 181,1 \\
\hline
\end{tabular}

Source: Eurostat (online data codes: tsdde410)

The situation can also be observed and appreciated through the graphical representations of the two indicators developments (Figure 1 and Figure 2).

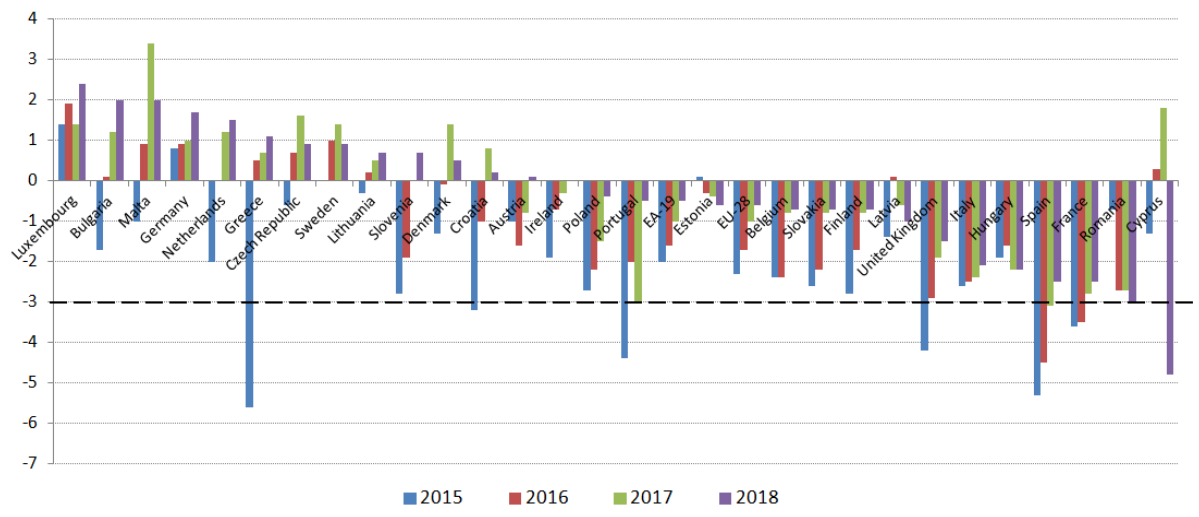

Figure 1 General government deficit/surplus developments in the European Union, 2015-2018 (\% of GDP)

Source: Own computation, based on the data available on Eurostat 
In 2015, the highest level of the government deficit as a percentage of GDP has reached $-5.6 \%$ in the United Kingdom, in 2016 and 2017 Spain recorded a government balance of $-4.6 \%$ and, respectively, $-3.1 \%$ of GDP, while in 2018 Cyprus registered the highest government deficit, of $-4.8 \%$ of GDP. In Spain, the government deficit related to GDP exceeded the reference value of $3.0 \%$ for three consecutive years: $2015,2016,2017$, however, showing a downward trend.

Also, in 2015 only three EU Member States reported government public surpluses Estonia (0.1\%), Germany (0.8\%) and Luxembourg (1.4\%) - and during the following years the situation has improved. In 2016, 10 states reported government public surpluses and in 2017, 12 countries recorded a positive budget balance.

The trends of the last two years, 2017 and 2018, indicate an improvement of the general government balance for more than half of the EU Member States, the best results being recorded by Portugal ( $+2.5 \%$ of GDP), Poland (+1, $2 \%$ of GDP) and Luxembourg (+ $1.0 \%$ of GDP). Bulgaria, Germany, Greece, Lithuania, Luxembourg and the Netherlands registered a higher surplus in 2018 than in 2017. On the other hand, in countries such as: Estonia, Latvia and Romania the general government deficit has increased during the last two years.

We can also note that for most Member States, the share of public debt in GDP is declining, but the evolution is slow. The decreases are favored, on the one hand, by the improved budgetary positions and, on the other hand, by the resumed GDP growth (European Commission, 2019).

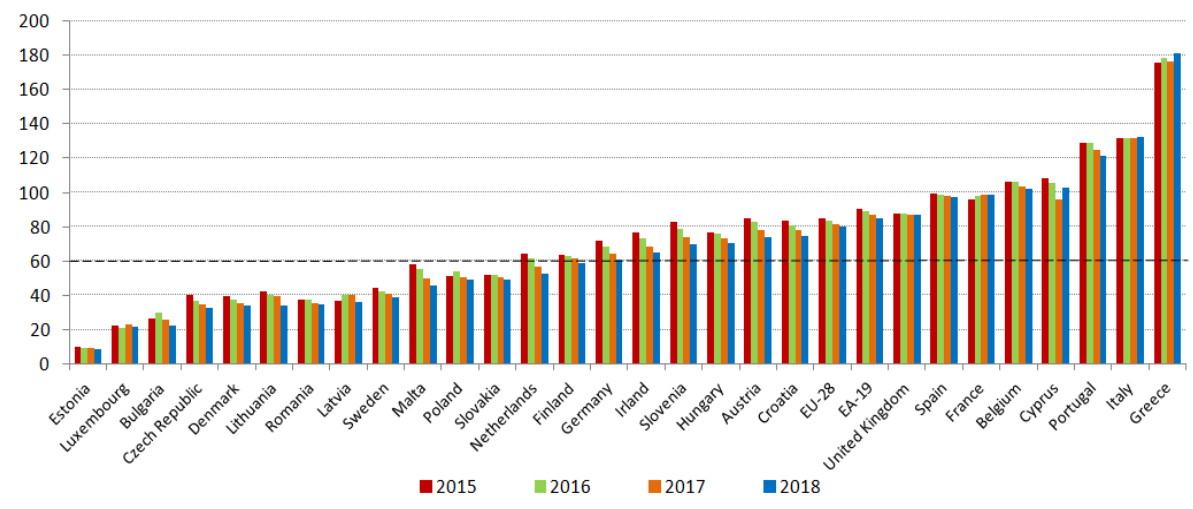

Figure 2 General government gross debt developments in the European Union, 2015-2018 (\% of GDP)

Source: Own computation, based on the data available on Eurostat

Thus, in 2015, a total of 18 Member States reported a debt rate of over $60 \%$ of GDP, the highest values being recorded by Greece (175.9\%), followed by Italy (131.6\%), Portugal (128\%), Cyprus (108.0\%), Belgium (106.4\%) and Spain (99.3\%). The lowest general government gross debts as a percentage of GDP were registered in Estonia (9.9\%), Luxembourg (22.0\%), Bulgaria (26.2\%), Czech Republic (40.0\%), Romania $(37.8 \%)$ and Denmark $(39.8 \%)$.

Compared to 2016, in 2017, the general government gross debt (in relation to GDP) improved for only two of EU Member States - Luxembourg (of 2.3 percentage points of GDP) and France (of 0.4 percentage points of GDP) -, while for the other 26 countries decreased, especially for: Cyprus ( -9.7 percentage points of GDP), Malta (5.3 percentage points of GDP), Austria ( $-4.8 \%$ percentage points of GDP) and Netherlands (-4.9 percentage points of GDP). 
In 2018, the situation of the general government balance and that of the government debt in the European Union are presented in Figure 3 and Figure 4.

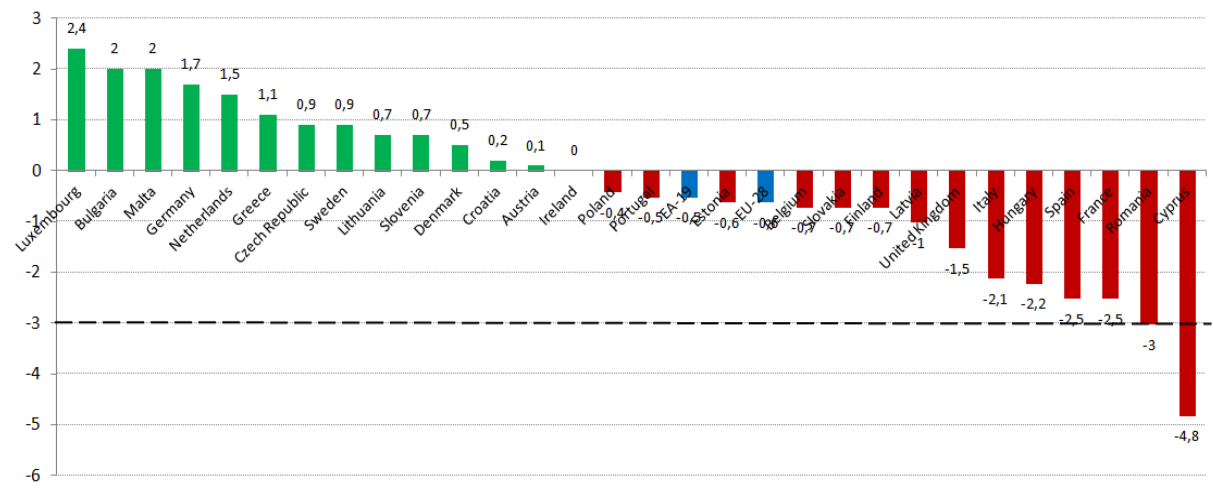

Figure 3 General government balance in the European Union, 2018 (\% of GDP)

Source: Own computation, based on the data available on Eurostat

Thus, in 2018, 13 EU-28 Member States achieved positive levels of the government balance: Austria $(+0.1 \%)$, Croatia $(+0.2 \%)$, Denmark $(+0.5 \%)$, Slovenia and Lithuania $(+0.7 \%)$, Sweden and the Czech Republic $(+0.9 \%)$, Greece $(+1.1 \%)$, the Netherlands $(+1.5 \%)$, Germany $(+1.7 \%)$, Malta and Bulgaria $(+2 \%)$, Luxembourg $(+2.4 \%)$.

Ireland reported a government balance and 12 EU Member States, namely: Poland, Portugal, Estonia, Belgium, Slovakia, Finland, Latvia, United Kingdom, Italy, Hungary, Spain, France, recorded deficits smaller than $3.0 \%$ of GDP. The lowest values were recorded in Poland (-0.4\%), Portugal (-0.5\%) and Estonia (-0.6\%). Romania ($3.0 \%)$ and Cyprus $(-4.8 \%)$ had deficits higher than or equal to $3 \%$ of GDP. In case of Cyprus the high deficit in 2018 is due, mainly, to the restructuring of Cyprus Cooperative Bank (Eurostat). Moreover, the support given by the Cypriot government in this regard has also affected the state's general government gross debt, which registered an exceptional increase from $95.8 \%$ of GDP in 2017 to $102.5 \%$ of GDP in 2018.

It is also worth noting that in 2018, both EU-28 and EA-19 registered a general government balance below the reference of $-3 \%$ of GDP, reaching the level of $-0.6 \%$ of GDP and respectively $-0.5 \%$ of GDP.

During the period of our analysis, due to favorable cyclical conditions and lower interest rates, the overall government deficit in the EU showed a downward trend, but this "is expected to end in 2019 , when the overall deficit is projected to slightly increase for the first time since 2009" (European Commission, 2019).

At the end of 2018, half of the EU Member States reported a government debt above the level of $60 \%$ of GDP, the highest of them being recorded in Greece (181.1\%), followed by Italy (132, 2\%), Portugal (121.5\%), Belgium (102.0\%), France (98.4\%) and Spain $(97.1 \%)$. The lowest government debt-to-GDP ratio were registered in Estonia (8.4\%), followed by Luxembourg (21.4\%) and Bulgaria (22.6\%).

Also, in 2018, the government debt-to-GDP ratio in EU-28 and in EA-19 reached the level of $80.0 \%$ and $85.1 \%$ respectively. 


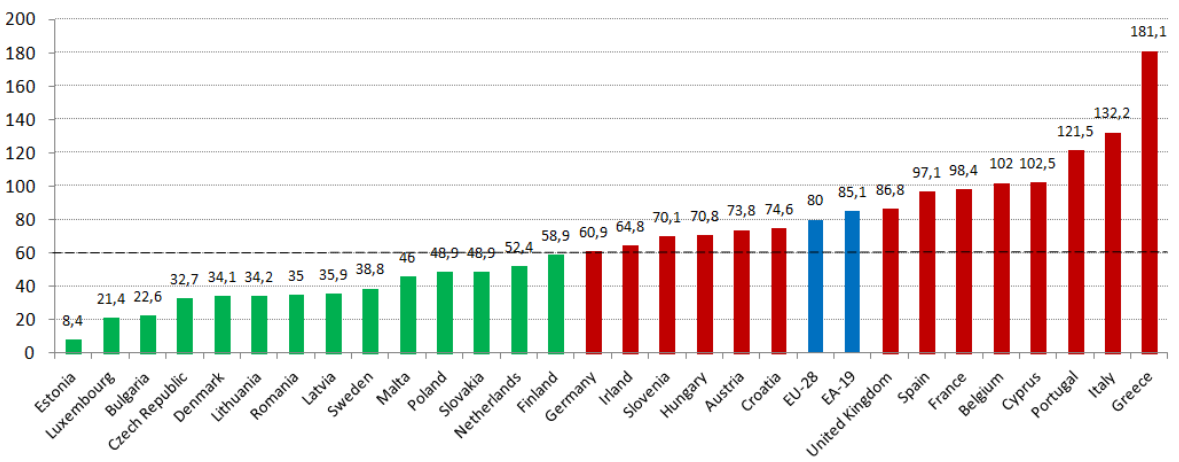

\section{Figure 4 General government gross debt in the European Union, 2018 (\% of GDP) \\ Source: Own computation, based on the data available on Eurostat}

The Commission estimates that in some EU Member States, general government gross debt will remain close to historical peak values, the expected budgetary adjustment being relatively limited or even negative.

\section{Conclusions}

In the context of macroeconomic imbalances, financial tensions and long-term challenges on the sustainability of the European Union's public finances, this paper aims to analyze the developments of the main indicators, the general government deficit/surplus and the general government gross debt (in relation to GDP), using the statistical data available on Eurostat, from 2015 to 2018.

The results allow us to appreciate that during the analyzed period, the European Union has made progress in correcting the macroeconomic imbalances, while some aspects of vulnerability still exist, and the evolution of the general government balance and the general government gross debt, as a whole, were favorable both for EU-28 as well as for EA-19.

In conclusion, the EU's public finances have improved, the public debt, although over the reference threshold of 60\%, has traveled a downward trend from 2015 until 2018, while the government deficit was below 1\% of GDP in 2018.

As a result and as recommended by the Commission, the implementation of structural reforms in the EU countries, the investment and also the responsible fiscal-budgetary policies, combined with decisive actions at European level, including the Investment Plan for Europe, can further contribute to renewing stability and increasing the prosperity of the European economy.

\section{References}

Bucur, I.A., Dragomirescu, S.D. (2013), An Analysis of the Fiscal Convergence Criteria in the European Union in Terms of the Sustainability, Studies and Scientific Researches. Economics Edition, No. 18, 137-149, available at http://sceco.ub.ro/index.php/SCECO/article/view/223;

European Commission (2019), Communication from the Commission to the European Parliament, the European Council, the Council, the European Central Bank and the EUROGROUP, 2019 European Semester: Assessment of progress on structural reforms, prevention and correction of macroeconomic imbalances, and results of in-depth reviews under Regulation (EU) No 1176/2011, available 
at $\quad$ https://ec.europa.eu/info/sites/info/files/file import/2019-european-

semester-communication-country-reports en_0.pdf;

Consolidated version of the Treaty on the Functioning of the European Union, available at https://eur-lex.europa.eu/resource.html?uri=cellar:2bf140bf-a3f8-4ab2b506-fd71826e6da6.0023.02/DOC_2\&format=PDF;

Excessive deficit procedure (EDP), available at https://eur-

lex.europa.eu/summary/glossary/excessive_deficit_procedure.html?locale=en; https://ec.europa.eu/eurostat/home?, Eurostat. 